\title{
SAPAAN DI LINGKUNGAN MAHASISWA JURUSAN PENDIDIKAN BAHASA DAN SASTRA INDONESIA FKIP UNIVERSITAS HALU OLEO
}

\author{
Trisna Wanti, ${ }^{1}$ Sulfiah, ${ }^{2}$ La Ode Balawa ${ }^{3}$ \\ pbsi.fkip.uho@gmail.com \\ 1,2,3, Jurusan Pendidikan Bahasa dan Sastra Indonesia, \\ Fakultas Keguruan dan Ilmu Pendidikan, Universitas Halu Oleo \\ Kampus Hijau Bumi Tridharma Anduonohu, Kendari, Indonesia
}

\begin{abstract}
Abstrak
Penelitian ini mengkaji tentang Sapaan Mahasiswa Jurusan Pendidikan Bahasa dan Sastra Indonesia FKIP Universitas Halu Oleo yang digunakan berdasarkan kebiasaan yang berlaku dalam kegiatan berinteraksi sehari-hari. Tujuan dari penelitian ini yaitu untuk mendeskripsikan sapaan mahasiswa di lingkungan Jurusan Pendidikan Bahasa dan Sastra Indonesia. Penelitian ini termasuk metode deskriptif kualitatif. Metode yang digunakan adalah metode simak, rekaman dan metode observasi. Data dianalisis secara deskriptif kualitatif. Berdasarkan hasil penelitian menunjukkan bahwa sapaan disesuaikan dengan kedudukan pembicara terhadap lawan bicara. Sapaan mahasiswa terhadap dosen menggunakan sapaan Pak, Ibu/Bu dan Prof. Sapaan mahasiswa terhadap pegawai administrasi menggunakan kata $P a k$, dan $I b u / B u$. Sapaan sesama mahasiswa seangkatan menggunakan kata Bro, Bebs, Gais, Kanda, Dinda. Sapaan terhadap mahasiswa junior menggunakan kata Dek, atau nama. Sapaan terhadap mahasiswa senior menggunakan kata Kak, dan Bang. Sapaan mahasiswa terhadap penjaga penjual di lingkungan gedung $\mathrm{C}$ menggunakan sapaan $\mathrm{Bu}, \mathrm{Om}$, dan Pak.
\end{abstract}

Kata kunci: Sapaan; Sosiolinguistik 


\section{PENDAHULUAN}

\subsection{Latar Belakang}

Bahasa merupakan salah satu unsur budaya yang sangat penting. Hal itu dapat dilihat dari fungsi dan peranannya dalam lingkungan masyarakat. Pentingnya bahasa bagi masyarakat atau manusia tidak perlu diragukan lagi. Pentingnya bahasa tidak saja dapat dilihat dari pemakaiannya dalam kehidupan sehari-hari, tetapi juga dapat dibuktikan dengan banyaknya perhatian para ilmuwan dan praktisi terhadap bahasa. Bahasa sebagai objek ilmu bukan sebagai monopoli para ahli bahasa, para ilmuwan dalam bidang lainpun menjadikan bahasa sebagai objek studi karena mereka memerlukan bahasa sekurang-kurangnya sebagaialat bantu untuk mengkomunikasikan berbagai hal (Finoza dalam Sukmawati, 2006:1)

Bahasa bagi sebagian orang diperlakukan sekedar alat komunikasi. Implikasinya adalah adanya kecenderungan yang lebih menekankan aspek komunikasi daripada aspek lain yang sebenarnya juga penting kaitannya dengan bahasa. Adanya kecenderungan menekankan aspek komunikasi itu pula yang pada gilirannya memunculkan pandangan yang tidak proporsional tentang komunikasi lisan dan komunikasi dalam bentuk tulisan. Jadilah kemudian komunikasi lisan dianggap jauh lebih penting dibandingkan komunikasi dalam bentuk tulisan.

Sapaan merupakan salah satu kategorisasi leksikal yang digunakan oleh penutur suatu bahasa yang menyandingkan realitas budaya mereka yang berkaitan dengan hubungan interpersonal dalam suatu komunitas suatu bahasa (Sulastri 2012: 3).

Sapaan merupakan salah satu bukti nyata komunikasi antarmanusia. Seorang menyapa orang lain karena adanya kebutuhan untuk berkomunikasi. Dalam komunikasi tersebut, relasi antarkomunikan mempengaruhi sapaan. Pemilihan sapaan diasumsikan terkait erat dengan sikap berbahasa dan cara pandang penutur dalam memosisikan dirinya terhadap lawan tuturnya. Dalam perkembangannya, pemakaian sapaan memiliki dinamika yang cukup menarik. Dinamika tersebut meliputi perkembangan pemakaian sapaan, pergeseran pengacuan sapaan, dan perubahan penyapaan.
Sapa menyapa diantara anggota masyarakat terjadi apabila seseorang berkomunikasi dengan orang lain. Proses sapa menyapa itu terjadi baik dalam lingkungan keluarga, masyarakat, instansi, maupun dalam lingkungan pendidikan. Dengan demikian, situasi pembicaraan sangat menentukan hubungan antara penyapa dan yang disapa. Hubungan antara penyapa dan yang disapa sangat menentukan sapaan yang dituturkan. Sehubungan dengan itu, variasi sapaan pada mahasiswa Jurusan Pendidikan Bahasa dan Satra Indonesia FKIP Universitas Halu Oleo ditimbulkan oleh beberapa faktor antara lain, tingkat kekerabatan, jenis kelamin, usia, dan situasi.

Pemilihan sapaan di lingkungan mahasiswa Jurusan Pendidikan Bahasa dan Sastra Indonesia FKIP Universitas Halu Oleo memegang peranan penting dalam berkomunikasi, Tulisan ini bertujuan untuk mendeskripsikan sapaan yang digunakan khususnya oleh mahasiswa Jurusan Pendidikan Bahasa dan Sastra Indonesia FKIP Universitas Halu Oleo, dengan asumsi bahwa selain mereka termasuk tingkat usia yang amat produktif dalam menggunakan sapaan, juga dimungkinkan mereka memiliki kekayaan sapaan atau penyapaan. Selain itu juga diharapkan dari penelitian ini dapat menggambarkan secara spesifik terkait dengan bentuk sapaan yang digunakan pada saat menyapa dalam kegiatan sehari-hari di lingkungan mahasiswa Jurusan Pendidikan Bahasa dan Sastra Indonesia FKIP Universitas Halu Oleo.

Sapaan adalah kata untuk saling merujuk dalam suatu pembicaraan menurut sifat hubungan diantara pembicara itu, misalnya anda, ibu, saudara. Sapaan terkait erat dengan nama dan sebutan. Nama yang dimaksud ialah kata untuk menyebut atau memanggil orang. Adapaun sebutan yang dimaksud ialah sesuatu yang disebut atau disebutkan, panggilan, nama dan gelar, dengan demikian, penelitan mengenai sapaan juga harus merujuk perihal nama dan sebutan.

Penelitian tentang sapaan di Indonesia telah banyak dilakukan salah satunya pada jurnal Tri Pujiati tahun 2017 dengan judul "Penggunaan Bentuk Sapaan Berdasarkan Perspektif Gender pada Mahasiswa Program Studi Sastra Indonesia Universitas Pamulang. Namun, fokus pada 
penelitian ini adalah membahas tentang bentuk sapaan pada mahasiswa Jurusan Pendidikan Bahasa dan Sastra Indonesia FKIP Universitas Halu Oleo. Karena penelitian menyangkut bentuk sapaan di lingkungan mahasiswa Jurusan Pendidikan Bahasa dan Sastra Indonesia FKIP Universitas Halu Oleo masih luput dari perhatian para peneliti. Oleh karena itu, peneliti tertarik untuk mengkaji tentang sapaan yang digunakan di lingkungan mahasiswa Jurusan Pendidikan Bahasa dan Sastra Indonesia FKIP Universitas Halu Oleo karena masih banyak yang membedakan sapaan-sapaan yang digunakan dalam kegiatan sehari-hari.

\subsection{Rumusan Masalah}

Berdasarkan latar belakang tersebut, maka yang menjadi masalah dalam penelitian ini adalah "Bagaimanakah sapaan di lingkungan mahasiswa Jurusan Pendidikan Bahasa dan Sastra Indonesia FKIP Universitas Halu Oleo"?

\subsection{Tujuan dan Manfaat Penelitian 1.3.1 Tujuan Penelitian}

Penelitian ini bertujuan untuk mendeskripsikan sapaan di lingkungan mahasiswa Jurusan Pendidikan Bahasa dan Sastra Indonesia FKIP Universitas Halu Oleo.

\subsubsection{Manfaat Penelitian}

Manfaat yang diharapkan melalui penelitian ini adalah sebagai berikut:

1. Sebagai konribusi pemikiran dalam hal memandang bahasa Indonesia.

2. Sebagai bahan pembanding dan rujukan bagi peneliti selanjutnya yang ingin mengkaji secara menyeluruh dan mendalam tentang sapaan di lingkungan mahasiswa FKIP Universitas Halu Oleo.

\subsection{Ruang Lingkup Penelitian}

Ruang lingkup penelitian ini dibatasi dalam aspek yaitu, sapaan yang berkaitan dengan penggunaannya oleh mahasiswa Jurusan Pendidikan Bahasa dan Sastra Indonesia FKIP Universitas Halu Oleo.

\subsection{Batasan Operasional}

Adapun batasan operasional dalam penelitian ini adalah:

1. Sapaan adalah kata untuk saling merujuk dalam suatu pembicaraan menurut sifat hubungan diantara pembicara itu, misalnya anda, ibu, saudara. Sapaan terkait erat dengan nama dan sebutan. Nama yang dimaksud ialah kata untuk menyebut atau memanggil orang. Adapaun sebutan yang dimaksud ialah sesuatu yang disebut atau disebutkan, panggilan, nama dan gelar.

2. Mahasiswa, yakni mereka yag masih berstatus mahasiswa di lingkungan FKIP Universitas Halu Oleo khususnya pada Jurusan Pendidikan Bahasa dan Sastra Indonesia

3. Bahasa adalah alat komunikasi yang efektif antarmanusia dalam berbagai macam situasi, bahasa dapat dimanfaatkan untuk menyampaikan gagasan

pembicara kepada pendengar atau penu lis kepada pembaca.

\section{KAJIAN PUSTAKA \\ 2.1 Sosiolinguistik}

Penelitian ini menggunakan pendekatan teori sosiolinguistik yang berhubungan dengan bentuk-bentuk kata pesapa. Nababan (dalam Sukmawati, 2006: 7) berpendapat bahwa sapaan adalah seorang pembicara untuk menyatakan sesuatu kepada orang lain. Sapaan tersebut merujuk kepada orang yang diajak bicara agar perhatiannya tertuju kepada pembicara.

Dalam kajian sosiolinguistik diakui anggapan bahwa antara struktur bahasa dan struktur masyarakat terdapat kaitan yang sistematis (Bright dalam Mulya dkk., 2004:13). Hal itu berarti bahwa variasi kata sapaan yang terdalam bahasa mencerminkan tingkat kepribadian pemakai bahasa atau masyarakat penuturnya. Keeratan hubungan itu dapat diterima sebab antara bahasa dan masyarakat merupakan satu kesatuan. Oleh karena itu berdasarkan konteks sosiolinguistik dapat ditentukan unsur-unsur yang dapat dikaji, misalnya siapa yang berbicara, dengan siapa atau kepada siapa ia berbicara, dimana dan dalam situasi yang bagaimana pembicaraan itu berlangsung, variasi apa saja yang muncul, dan topik- 
topik yang dibicarakan (Fishman dalam Mulya dkk., 2004: 13).

Sosiolinguistik lazim didefenisikan sebagai ilmu yang mempelajari ciri dan berbagai variasi bahasa, serta hubungan di antara bahasawan dengan ciri dan fungsi itu dalam suatu masyarakat bahasa. Fishman (dalam Pateda, 2013: 2). Di sini tergambar dengan jelas bahwa sosiolinguistik tidak memusatkan perhatiannya pada fenomena kebahasaan saja, melainkan juga memusatkan perhatian pada sosial tingkah laku, sikap bahasa, tingkah laku nyata terhadap bahasa dan pemakai bahasa. Sosiolinguistik sebenarnya tidak memperhatikan aturan permainan dalam bahasa, tetapi yang diperhatikan bagaimana pemakaina bahasa sehingga dia menjalankan fungsinya semaksimal mungkin. Sebelum lahirnya sosiolinguistik orang lebih banyak memperhatikan struktur, dan setelah timbul konflik-konflik bahasa karena fungsinya, maka orang mencari jalan dan lahirlah sosiolinguistik, dengan uraian ini jelaslah kepada kita bahwa sosiolinguistik lahir karena ingin menempatkan bahasa sesuai dengan fungsi dan kedudukannya. Fungsi utama bahasa adalah sebagai alat komunikasi.

Dari beberapa pendapat para ahli tersebut, maka dapat disimpulkan bahwa sosiolinguistik adalah suatu cabang ilmu linguistik yang mempelajari bahasa dan pemakaian bahasa dalam masyarakat.

Sapaan adalah mengacu pada seseorang di dalam interaksi linguistik yang dilakukan secara langsung (Crystal dalam Martina, 2004: 5). Brown dan Ford dalam tulisannya yang berjudul Addres in American English yang dikutip oleh Hutcheson (dalam Martina, 2004: 6) mengatakan bahwa dalam interaksi orang menggunakan pilihan bentuk linguistik berdasarkan hubungan antara pembicara dan mitra bicara berdasarkan rasional. Mereka menemukan kaidah sapaan berupa pilihan nama pertama yang sifatnya resiprokal atau gelar diikuti nama terakhir. Resiprokal hubungan yang tidak simetris ditemukan apabila terdapat perbedaan usia atau pangkat dalam jabatan.

Menurut Kridalaksana (dalam Sukmawati, 2006: 7), semua bahasa mempunyai bahasa tutur sapa. Oleh karena itu, bahasa merupakan salah satu cara penyampaian maksud dari yang menyapa kepada orang yang disapa, baik secara lisan maupun tertulis dalam bentuk perangkat kata-kata. Tutur sapa sebagai suatu sistem untuk menyampaikan maksud mempunyai peranan penting karena sistem penyapa yang berlaku dalam bahasa-bahasa tertentu berbeda dengan sistem penyapa yang berlaku dalam bahasa lain.

\subsection{Fungsi Bahasa}

Yang dimaksud dengan fungsi bahasa adalah nilai pemakaian bahasa yang dirumuskan sebagai tugas pemakaian bahasa itu di dalam kedudukan yang diberikan kepadanya (Halim dalam Sugihastuti, 2014: 10).

Menurut Mahayana, (2015: 7) Manusia adalah makhluk berbahasa. Ia tidak dapat melepaskan diri dari kehidupan bahasa. Jika tetap ingin bertahan dalam kehidupan sosialnya, ia mesti menggunakan bahasa, tanpa itu ia akan terkucil, menyendiri dan hidup di tengah makhluk bukan manusia. Sejak lahir manusia sudah masuk ke dalam dunia berbahasa. Mulamula ia mencoba memahami perangkat bahasa (kosakata) yang paling dekat dengan dirinya. Kemudian belajar mengenal bendabenda di sekitarnya. Sejalan dengan perkembangan usia dan daya pikirnya, pengenalan tentang dunia sekitar menjadi pengetahuan dan sekaligus menandainya melalui kemampuannya berbahasa. Lambat laun ia pun mengenal dan memahami bahasa mulai dari kosakata yang paling sederhana yang menyangkut kosakata benda-benda di sekitarnya sampai ke kosakata yang abstrak dan berada di luar lingkungannya. Ketika manusia menyadari betapa penting bahasa dalam kehidupan, ia pun dapat menangkap adanya sejumlah fungsi yang melekat pada bahasa.

Dalam komunikasi yang mempergunakan bahasa, ada beberapa faktor yang turut menentukan. Faktor ini dikemukakan oleh Roman Jakobson yang dikutip oleh D. Hymes (dalam Pateda, 2013:

5), yakni:

a. Pembicara (senders, addressors,
spokesman)
b. Pendengar (receivers, addressors,
interpreters)
c. Tersedianya alat 
d. Faktor lain yang muncul bersama-sama pembicara

e. Setting termasuk kesediaan menerima

f. Bentuk-bentuk pesan

g. Topik dan penjelasan pembicaraan

h. Peristiwa itu sendiri

\subsection{Sistem}

Pengertian sistem sapaan yang diapakai dalam penelitian ini ialah seperangkat kata-kata atau ungkapan yang dipakai untuk menyebut dan memakai para pelaku dalam suatu peristiwa bahasa. Para pelaku ialah pembicara (pelaku satu) selanjutnya disebut penyapa, yang diajak bicara (pelaku kedua) sealnjutnya disebut pesapa dan yang disebut dalam pembicaraan (pelaku ketiga). Bentuk sapaan ini dapat berupa kata ganti, nama diri, istilah kekerabatan, kata-kata deiksis atau penunjuk, dan nominal. (Kridalaksana dalam Kamma, 2015: 6).

Mahmud dkk. (dalam Suharyanto dkk., 2008: 3) mengacu pada Brown dan Gilman mengatakan bahwa ada dua macam hubungan antara pembicara dan lawan bicara. Hubungan yang pertama ialah power semantic dan hubungan yang kedua ialah solidarity semantic. Istilah power digunakan untuk menyatakan hubungan sekurangkurangnya dua persona yang nonresiprokal. Power semantic sama halnya dengan nonresiprokal (tak berbalasan) yang di dasarkan pada kekuatan fisik, kekayaan, umur, jenis kelamin, status dan lain-lain. Solidarity semantic adalah hubungan yang sifatnya simetris atau resiprokal, yang disebabkan adanya kesamaan umur, kesamaan sekolah, kesamaan orang tua (seketurunan), atau kesamaan profesi.

Sistem bahasa yang dibicarakan diatas adalah berupa lambang-lambang dalam bentuk bunyi. Artinya lambanglambang itu berbentuk bunyi yang lazim disebut bunyi ujar atau bunyi bahasa. Setiap lambang bahasa melambangkan sesuatu yang disebut makna atau konsep.

\subsection{Sapaan dalam Berbahasa}

Bahasa adalah suatu sistem simbol lisan yang arbitrer yang dipakai oleh anggota suatu masyarakat bahasa untuk berkomunikasi dan berinteraksi antar sesamanya, berdasarkan pada budaya yang mereka miliki bersama (Dardjowidjojo
2014: 16). Bahasa juga diartikan sebagai penggunaan kode yang merupaka gabungan fonem sehingga membentuk kata dengan aturan sintaksis untuk membentuk kalimat yang memiliki arti. Keraf (1984:16) mengemukakan bahwa bahasa adalah alat komunikasi anatara anggota masyarakat berupa lambang bunyi suara yang dihasilkan oleh alat ucap manusia. Bahasa adalah saluran perumusan maksd yang melahirka perasaan dan memungkinkan adanya kerja sama anatar individu. Selain itu juga, bahasa berfungsi sebagai medium untuk melakukan tindakan dan cerimanan budaya penuturnya.

Kata sapaan digunakan untuk menegur sapa orang yang diajak berbicara. Setiap penggunaan kata sapaan dalam suatu bahasa dengan bahasa yang laini tentulah berbeda. Oleh karena itu, penggunaan kata sapaan dalam suatu bahasa yang dapat mencerminkan sistem interaksi sosial masyarakat penuturnya. Jal ini dapat terjadi karena tiap-tiap budaya memiliki kaidah bahasa dan nilai masyarakat yang berbeda. Perbedaan ini akan konsekuen bagi orang yan akan mempelajari dan menggunakannya dalam tindak komunikasi. Kata sapaan berguna sebagai ajakan percakapa, teguran, ucapan, seta penggunaan kata yang berbeda sesuai sifat diantara pembicara dengan lawan bicaranya.

Sapaan hampir selalu dipakai dalam berkomunikasi, baik secara lisan maupun secara tertulis. Tanpa menggunakan bentuk sapaan, kepada siapa pembicaraan itu di tujukan sering menjadi tidak jelas. Kartomihardjo (dalam Suhaebah dkk., 2007:126) mengungkapkan bahwa sapaan merupakan salah satu komponen bahasa yang penting karena dalam sapaan itu dapat ditentukan suatu interaksi tertentu akan berlanjut. Dikatakan pula bahwa setiap kelompok masyarakat mempunyai pedoman yang berupa adat kebiasaan, norma, nilai, dan peraturan yang ditetapkan bersama oleh para anggota masyarakat yang bersangkutan untuk mengatur warganya. Pedoman yang digunakan untuk mengatur perilaku masyarakat tersebut juga terdapat pada bahasa yang dimilikinya (Kartomihardjo dalam Suhaebah dkk, 2007: 126).

Crystal (dalam Suhaebah dkk., 2007: 126) mengatakan bahwa sapaan adalah cara mengacu seseorang di dalam iteraksi linguistik yang dilakukan secara 
langsung. Dalam interaksi linguistik, tipetipe partisipan dibedakan berdasarkan situasi sosial dan kaidah-kaidah yang dikemukakan untuk menjelaskan penggunaan istilah yang dilakukan oleh si pembicara, seperti penggunaan nama pertama, gelar, dan pronomina. Sapaan berbeda dengan salam dan panggilan. Sebagaimana dikatakan Chaika (dalam Suhaebah dkk, 2007: 126), sapaan acap kali merupakan bagian dari salam. Sapaan hampir selalu digunakan untuk menyatakan kekuasaan dan kebersamaan, sedangkan salam dapat bervariasi bergantung pada suasana batin kedua penuturnya. Salam adalah ungkapan yang digunakan untuk mengawali dan mengakhiri suatu interaksi verbal dan memiliki bentuk yang bervariasi bergantung pada suasana batin orang yang memberi salam. Panggilan adalah ungkapan yang digunakan untuk menarik perhatian seseorang. Biasanya panggilan ditandai dengan intonasi akhir naik dan dilanjutkan dengan percakapan.

Dari beberapa pendapat para ahli tersebut, maka dapat disimpulkan bahwa sapaan adalah seperangkat kata-kata atau ungkapan yang dipakai untuk menyebut dan memanggil para pelaku dalam peristiwa bahasa. Sedangkan bentuk sapaan yang dipakai ditentukan oleh umur, jenis kelamin, kedudukan, hubungan keluarga, situasi, keakraban, dan topik pembicaraan antara penyapa dengan yang disapa.

\subsection{Penggunaan Bahasa}

Menurut Sudaryanto, (dalam Sulastri dkk., 2014: 7) bahasa merupakan sistem referensial karena pada hakikatnya dia menjadi sistem yang dimanfaatkan akal budi untuk menangkap, mengolah, membentuk, menafsirkan, menerjemahkan, mengungkapkan, dan membeberkan segala yang dapat diacu oleh manusia. sedangkan menurut Harimurti Kridalaksana bahasa ialah sistem lambang yang arbitrer yang dipergunakan oleh anggota suatu masyarakat untuk berinteraksi, dan mengidentifikasikan diri. Sebagai alat untuk berinteraksi, bahasa antara lain digunakan dalam komunikasi, baik di dunia pendidikan, di lingkungan instansi pemerintah, maupun dalam kehidupan masyarakat.

Bahasa adalah alat komunikasi yang efektif antar manusia. Dalam berbagai macam situasi, bahasa dapat dimanfaatkan untuk menyampaikan gagasan pembicara kepada pendengar atau penulis kepada pembaca. Tentu saja, pada tiap-tiap situasi komunikasi yang dihadapi dipilih salah satu dari sejumlah variasi pemakaian bahasa. Berbahasa dipasar antara pembeli, antara pembeli dan penjual, atau antara penjual pasti berbeda dengan berbahasa di depan orang yang dihormati, antara atasan dan bawahan, antara pasien dan dokter, antara murid dan guru, antara anggota rapat dinas, dan sebagainya. Setiap situasi memungkinkan seorang memilih variasi bahasa yang akan digunakannya. Faktor pembicara, pendengar, pokok pembicaraan, tempat dan suasana pembicaraan berpengaruh pada seseorang dalam memilih variasi bahasa (Moeliono dalam Sugihastuti, 2014: 8).

Menurut Chaer, (2010: 11-12) bahasa adalah sebuah sistem lambang berupa bunyi, bersifat arbitrer, produktif, dinamis, beragam, dan manusiawi. Selain itu bahasa juga dibentuk oleh sejumlah komponen yang berpola secara tetap dan dapat dikaidahkan. Bagi orang yang mengerti sistem bahasa Indonesia akan mengakui bahwa susunan "ibu meng...seekor...di..." adalah sebuah kalimat bahasa Indonesia yang benar sistemnya, meskipun ada sejumlah komponen yang ditinggalkan. Tetapi susunan "meng ibu se ikan goreng di ekor dapur" bukanlah kalimat bahasa Indonesia yang benar karena tidak tersusun menurut sistem kalimat bahasa Indonesia. Sebagai sebuah sistem, bahasa selain bersifat sistematis juga bersifat sistemis. Dengan sistematis maksudnya, bahasa itu tersusun menurut suatu pola tertentu, tidak tersusun secara acak atau sembarangan. Sedangkan sistemis artinya sistem bahasa itu bukan merupakan sebuah sistem tunggal melainkan terdiri dari sejumlah subsistem yakni fonologi, subsistem morfologi, subsistem sintaksis, dan subsistem leksikon.

\subsection{Penggunaan Sapaan}

Sapaan merupakan salah satu kategorisasi leksikal yang digunakan oleh penutur suatu bahasa yang menyandingkan realitas budaya mereka yang berkaitan dengan hubungan interpersonal dalam suatu komunitas suatu bahasa (Sulastri 2012: 3). 
Sapaan adalah kata atau frasa untuk saling merujuk dalam suatu pembicaraan dan dapat berbeda-beda menurut sifat hubungan diantara pembicara itu, misalnya anda, ibu, saudara. Sapaan terkait erat dengan nama dan sebutan. Nama yang dimaksud ialah kata untuk menyebut atau memanggil orang. Adapaun sebutan yang dimaksud ialah sesuatu yang disebut atau disebutkan, panggilan, nama dan gelar, dengan demikian, penelitan mengenai sapaan juga harus merujuk perihal nama dan sebutan. Beberapa tulisan mengenai penamaan yang telah dipublikasikan antara lain sebagai berikut

Menurut Chaer (1995:43-52) menyatakan bahwa penamaan merupakan proses pelambangan suatu konsep untuk mengacu sesuatu referen yang berada di luar bahasa. Mengingat bahasa merupakan sesuatu yang arbitrer, anatara satuan kebahasaan dan sesuatu yanh dilambanginya tidak memiliki hubngan baik hubungan wajin sehingga pemberian namapun dapat bersifat arbitrer.

Penggunaan bahasa khususnya bentuk-bentuk sapaan, selain memiliki kaitan sosial juga memiliki hubungan yang sangat erat dengan pola-pola budaya berbahasa sebagai salah satu wujud prilaku sosialnya. Perangkat perilaku berbahasa itu berada dalam konteks kebudayaan, dan setiap wujud perilaku berbahasa itu muncul dalam situasi tersebut. Oleh karena itu bentuk-bentuk kebahasaan secara fungsional dapat dilihat dan digunakan sesuai dengan latar situasi berlangsungnya komunikasi verbal dalam sistem komunikasi sosial. Variasi bentuk sapaan mempunyai fungsi tertentu dalam konteks sosiolinguistik, artinya variasi bentuk sapaan itu memperlihatkan adanya hubungan anatara segi kebahasaan dan faktor di luar bdang kebahasaan. Penggunaan sapaan dalam suatu bahasa mencerminkan sistem interaksi sosial masyarakat penuturnya. Sebagai contoh, dalam masyarakat Madura, seseorang yang berstatus sosial rendah dalam menyapa mitra tutur yang berstatus sosial yang lebih tinggi akan menggunakan sapaan orang kedua tunggal yang mempunyai arti 'kamu', seperti padhana,dhika, panjhennengngan, sampeyan 'kamu (hormat)', atau ajunan 'kamu (sangat hormat)' dan tidak akan menggunakan kata sapaan orang kedua tunggal ba na, ba'en, ba'eng, kakeh, atau seda ' kamu (netral)', karena pemakaian tersebut itu menunjukkan bahwa masyarakat Madura mengenal stratifikasi sosial. Penggunaan kata sapaan yang yang dianggap melanggar norma sosial tersebut adalah penggunaan yang tidak sesuai dengan kaidah sapaan.

\section{METODE DAN TEKNIK \\ PENELITIAN}

\subsection{Jenis dan Metode Penelitian}

\subsubsection{Jenis Penelitian}

Jenis penelitian ini termasuk penelitian lapangan dalam hal ini peneliti langsung ke lokasi penelitian yaitu di lingkungan FKIP Universitas Halu Oleo untuk mendapatkan data secara objektif sesuai dengan masalah yang diteliti yaitu tentang bentuk sapaan mahasiswa Jurusan Pendidikan Bahasa dan Sastra Indonesia FKIP Universitas Halu Oleo.

\subsubsection{Metode Penelitian}

Metode yang digunakan dalam penelitian ini adalah metode deskriptif kualitatif. Metode ini merupakan penggambaran atau menyajikan data berdasarkan kenyataan-kenyataan secara objektif, sistematis dan akurat mengenai data, sifat-sifat serta hubungannya dengan masalah penelitian. Metode ini bertujuan membuat deskriptif sesuai dengan kenyataan keadaan data secara alamiah, sehingga data yang ada berdasarkan fenomena dan fakta yang memang sesuai dengan kenyataan pada penuturnya.

\subsection{Data dan Sumber Data 3.2.1 Data}

Data dalam penelitian ini adalah data lisan yang diperoleh dari hasil lapangan yang berupa tuturan-tuturan yang bersumber dari mahasiswa Jurusan Pendidikan Bahasa dan Sastra Indonesia. Data yang digunakan adalah data yang sesuai dengan objek penelitian yaitu berupa bentuk-bentuk sapaan di lingkungan mahasiswa Jurusan Pendidikan Bahasa dan Sastra Indonesia FKIP Universitas Halu Oleo.

\subsubsection{Sumber Data}

sumber data dalam penelitian ini adalah percakapan-percakapan yang diperoleh dari mahasiswa Jurusan 
Pendidikan Bahasa dan Sastra Indonesia. penelitian dilakukan di lingkungan FKIP Univesitas Halu Oleo yaitu di sekitar ruangan perkuliahan PBSI, ruang ujian PBSI, di sekitar ruang jurusan PBSI, ruangan administrasi. Percakapan yakni dibatasi untuk mahasiswa Jurusan Pendidikan Bahasa dan Sastra Indonesia yang masih berstatus sebagai mahasiswa yang berinteraksi dalam kegiatan sehari-hari.

\subsection{Instrumen Penelitian}

Peneliti merupakan instrumen kunci, baik dalam pengumpulan data maupun dalam analisis data. Untuk mendukung instrumen utama, peneliti dibantu dengan instrumen tambahan yaitu berupa panduan observasi. Panduan observasi disusun berdasarkan pengamatan tentang bentuk-bentuk sapaan yang digunakan oleh mahasiswa Jurusan Pendidikan Bahasa dan Sastra Indonesia FKIP Universitas Halu Oleo.

\subsection{Teknik Pengumpulan Data}

Sesuai dengan rancangan penelitian serta data dan sumber data, maka teknik pengumpulan data yang digunakan dalam penelitian ini adalah sebagai berikut:

1. Teknik observasi maksudnya adalah peneliti mengamati secara langsung kegiatan berbahasa mahasiswa Jurusan Pendidikan Bahasa dan Sastra Indonesia FKIP Universitas Halu Oleo untuk mencatat data yang berkenaan dengan masalah penelitian.

2. Teknik simak yaitu teknik yang digunakan peneliti untuk memperoleh data dengan cara menyimak setiap penutur sumber informasi yaitu pada mahasiswa Jurusan Pendidikan Bahasa dan Sastra Indonesia dalam hal ini adalah sejumlah percakapan yang di dalamnya terdapat sapaan yang dapat dijadikan sebagai data.

\subsection{Teknik Analisis Data}

Analisis data dilakukan dengan cara teknik analisis deskriptif kualitatif, pada tahap ini data-data yang diperoleh di lapangan dianalisis secara teliti dan cermat, selanjutnya diklasifikasikan berdasarkan masalah penelitian, yaitu menyangkut sapaan di lingkungan mahasiswa Jurusan Pendidikan Bahasa dan Sastra Indonesia FKIP Universitas Halu Oleo.

\section{BAB IV}

HASIL DAN PEMBAHASAN

4.1 Penyajian Data

Data dalam penelitian ini didasarkan pada data-data yang menyangkut gambaran akan kondisi dari pada objek penelitian. Untuk memperoleh data tersebut peneliti menggunakan beberapa cara dalam mendukung data-data yang ada. Perolehan data didasarkan pada hasil pengamatan langsung peneliti terhadap objek penelitian. Dalam hal ini adalah bentuk sapaan di lingkungan mahasiswa Jurusan Pendidikan Bahasa dan Sastra Indonesia FKIP Universitas Halu Oleo. Di samping itu juga data lain yang diperoleh dari proses menyimak percakapan-percakapan yang digunakan khususnya oleh mahasiswa Jurusan Pendidikan Bahasa dan Sastra Indonesia FKIP Universitas Halu Oleo dalam kegiatan sapa-menyapa sehari-hari. Penelitian dilakukan selama satu bulan.

\subsection{Analisis Bentuk Sapaan \\ Mahasiswa Jurusan \\ Pendidikan Bahasa dan \\ Sastra Indonesia \\ FKIP Universitas Halu Oleo}

Dalam kegiatan sehari-hari khususnya dalam dunia kampus kita tidak lepas dari kegiatan komunikasi yang mengharuskan kita untuk menyapa seseorang dan untuk menyapa seseorang itu kita menggunakan kata sapaan. Jadi kata sapaan adalah kata yang digunakan untuk menyapa orang yang diajak bicara. Berbagai bentuk sapaan yang dipakai dalam banyak bentuk dan acuan. Setiap tindakan ujaran yang dihasilkan dalam peristiwa ujaran yang tercipta antara orang yang menyapa terhadap orang yang disapa dan juga karena adanya interaksi sosial bersemuka dalam ragam apapun yang melibatkan salah satu yang penting, yaitu dari segi penyapaan. Bentuk sapaan yang dipilih dalam penelitian ini, yaitu bentuk-bentuk sapaan yang digunakan oleh mahasiswa Jurusan Pendidikan Bahasa dan Sastra Indonesia FKIP Universitas Halu Oleo.

\subsubsection{Sapaan Mahasiswa terhadap} Dosen

Dalam lingkungan kampus atau lingkungan perkuliahan, khususnya di lingkungan mahasiswa Jurusan Pendidikan 
Bahasa dan Sastra Indonesia pasti memiliki bentuk sapaan ketika menyapa dosen. Seorang mahasiswa akan menyapa dosen dengan sopan dalam memulai suatu pembicaraan. Maka seperti kenyataan yang ada bahwasanya sapaan atau penyapaan yang sering digunakan oleh seorang mahasiswa kepada dosen adalah menggunakan sapaan Pak/Bapak jika dosen tersebut adalah dosen laki-laki, sapaan Prof yaitudosen yang memiliki gelar lebih tinggi, dan sapaan $B u / I b u$ jika dosen tersebut adalah dosen perempuan.

\section{Data 1}

Konteks:

Pada saat mahasiswa bertemu dosen yang baru keluar dari ruang ujian PBSI, percakapan terjadi pada hari kamis pukul 13:15. Mahasiswa menghampiri dosen yang saat itu masih berada di sekitar ruang Jurusan Pendidikan Bahasa dan Sastra Indonesia untuk konsultasi masalah tugas akhir. Berikut percakapannya.

Mahasiswa: "Permisi Pak, saya mau konsul hasil penelitianku".

Dosen A: "Ini sudah berapa kali konsul”?

Mahasiswa I: "baru pertama kali pak".

Dosen A: "Saya periksa dulu nanti kamu hubungi saya kembali".

Analisis data:

Dari percakapan di atas terdapat kata sapaan Pak. Sapaan Pak merupakan kata sapaan yang digunakan untuk menyapa dosen laki-laki. Percakapan di atas di lakukan oleh mahasiswa I dengan dosen A. Sebelum melakukan proses tutur sapa mahasiswa I sedang menunggu dosen A yang saat itu sedang menguji, mahasiswa tersebut menunggu dosen sampai selesai menguji pada pukul 13:15. Terjadinya percakapan adalah ketika seorang mahasiswa menghampiri dosen pembimbing untuk konsultasi mengenai tugas akhir. Kemudian dosen memberitahu mahasiswa bahwa beliau akan memeriksa terlebih dahulu hasil penelitian mahasiswa tersebut. Jadi dapat dilihat bahwa mahasiswa tersebut menyapa dosen dengan sopan dalam memulai suatu percakapan yang telah diketahui bahwa proses percakapan tersebut dilakukan dalam situasi formal, yakni di lingkungan Jurusan Pendidikan Bahasa dan Sastra Indonesia.

Data 2

Konteks:
Pada saat mahasiswa sedang berada di sekitar ruang perkuliahan A3.2 Jurusan Pendidikan Bahasa dan Sastra Indonesia tiba-tiba datang seorang dosen yang menghampiri salah satu mahasiswa untuk meminta tolong. Berikut percakapan.

Dosen A : "Tolong kamu ambilkan kunci ruangan saya sama dosen $B$ di ruang kuliah A3.6".

Mahasiswa I : "Assalamualaikum Bu, saya disuruh dosen A untuk mengambil kunci ruangan".

Dosen B : :Nanti saya yang bawa karena saya juga mau kembali ke ruangan".

Mahasiswa I :"Iya bu, permisi”.

Analisis data:

Dari percakapan di atas terdapat kata sapaan $\boldsymbol{B u}$. Sapaan $\boldsymbol{B} \boldsymbol{u}$ merupakan kata sapaan yang digunakan mahasiswa untuk menyapa dosen perempuan, percakapan dilakukan oleh mahasiswa I dengan dosen A dan dosen B. Konteks yang melatarbelakangi terjadinya percakapan adalah ketika mahasiswa sedang menunggu dosen di sekitar ruang perkuliahan A3.2 untuk konsultasi mengenai tugas akhir. Tibatiba datang dosen A meminta tolong kepada salah satu mahasiswa untuk mengambilkan kunci ruangannya kepada dosen B yang saat itu dosen B sedang mengajar di lantai dua yakni di ruang kuliah A3.6. Kemudian mahasiswa berjalan menuju ruang kuliah A3.2 untk mengambil kunci ruangan tesebut, mahasiswa menyapa dosen B yang memiliki posisi dan kedudukan lebih tinggi dengan berkata "assalamualaikum $\boldsymbol{B} \boldsymbol{u}$, saya disuruh dosen A untuk mengambil kunci ruangan". Pada saat itu dosen B baru selesai mengajar, sehingga dosen B berkata nanti saya yang bawa karena saya juga mau kembali ke ruangan.

Data 3

Konteks:

Pada saat mahasiswa menunggu dosen yang sedang menguji di dalam ruang ujian seminar PBSI pada hari kamis pukul 10:00. Setelah selesai menguji mahasiswa menghampiri dosen yang berada di dalam ruangan tersebut, berikut percakapan. 
Mahasiswa I :

"Maaf Pak, saya mahasisw a Jurusan Pendidikan Bah asa Indonesia kelas $B$ angkatan 2017 mau menghadap nilai mata kuliah strategi pembelajaran yang nilainya $E$ ".

Dosen A : "Coba kamu print KHS mu lalu perlihatkan ke saya, karena biasanya yang dapat nilai $E$ itu tidak mengikuti ujian atau tidak mengikuti perkuliahan sama sekali".

Mahasiswa I : "Iya baik pak".

Analisis data:

Dari percakapan di atas terdapat kata sapaan Pak. Sapaan Pak merupakan kata sapaan yang digunakan mahasiswa untuk menyapa dosen laki-laki, percakapan dilakukan oleh mahasiswa I dengan dosen A. Proses terjadinya percakapan adalah dalam situasi formal, percakapan tersebut terjadi di ruang ujian seminar Jurusan Pendidikan Bahasa dan Sastra Indonesia. Percakapan dilakukan secara langsung oleh mahasiswa kepada dosen, pada data tersebut terdapat sebuah konteks yang melatarbelakangi terjadinya percakapan yaitu seorang mahasiswa yang sedang menghadap mengenai nilainya yang bermasalah yakni nilai yang tidak memenuhi standar kelulusan. Mahasiswa menghampiri dosen yang telah selesai menguji tersebut dengan bertutur sapa yang sopan dan bertanya mengapa nilai yang keluar adalah nilai $\mathrm{E}$ padahal mahasiswa tersebut sudah mengikuti perkuliahan, kemudian dosen memberitahu mahasiswa yang sedang menghadap tersebut untuk memperlihatkan KHS nya agar bisa diubah menjadi nilai yang memenuhi standar kelulusan.

\section{Data 4}

Konteks: Pada saat mahasiswa menunggu dosen pembimbing yang sedang mengajar di ruang perkuliahan A3.2 Jurusan Pendidikan Bahasa dan Sastra Indonesia pada hari senin tepat pukul 10:00. Seorang mahasiswa menghampiri dosen ketika sudah keluar dari ruangan tersebut. Berikut percakapannya.

Mahasiswa I : "Maaf Prof, saya mau menyebar ujian seminar hasil hari kamis pukul 11:00”.
Dosen A :"Saya di sini sebagai pembimbing yah, kamu simpan saja di ruangan saya".

Analisis data:

Dari percakapan di atas terdapat kata sapaan Prof. Sapaan Prof juga digunakan mahasiswa untuk menyapa dosen, percakapan dilakukan oleh mahasiswa I dengan dosen A. Konteks yang melatarbelakangi terjadinya percakapan adalah di mana terdapat seorang mahasiswa yang sedang menghampiri dosen yang saat itu baru selesai mengajar di ruang perkuliahan A3.2. Mahasiswa menyapa dosen pembimbingnya untuk menyebar hasil penelitian karena mahasiswa tersebut akan mengikuti ujian seminar hasil pada hari kamis pukul 11:00. Kemudian dosen memberitahu agar mahasiswa tersebut membawa hasil penelitian di ruangannya saja yang berada di lantai dua belok kiri karena pada saat itu dosen tersebut langsung menuju ke mobilnya.

\section{Data 5}

Konteks:

Pada saat mahasiswa sedang berada di sekitar ruang ujian Jurusan Pendidikan Bahasa dan Sastra Indonesia, tiba-tiba datang dosen A yang sudah selesai menguji dan dosen A tersebut ingin pulang tetapi tidak membawa kendaraan kemudian terdapat salah satu mahasiswa yang menghampiri dan menawarkan kendaraannya untuk dipakai dosen A. Berikut percakapan.

Mahasiswa I: "Bos, kita pake saja motorku $k$ alau sudah mau pulang saya pulang dengan temanku”.

Dosen A : "Iya kalau begitu kebetulan saya tidak bawa kendaraan, nanti motormu kamu datang ambil di rumah".

Analisis data:

Dari percakapan di atas terdapat sapaan Bos. Sapaan Bos pada data tersebut digunakan oleh salah satu mahasiswa ketika menyapa dosennya, percakapan dilakukan oleh mahasiswa I dengan dosen A. Sebelum terjadinya percakapan terdapat dosen A yang baru selesai menguji ingin pulang tetapi dosen tersebut tidak membawa kendaraan, tiba-tiba datang mahasiswa I menawarkan kendaraan untuk dipakai dosennya karena keduanya sudah sama-sama saling kenal dan akrab. Sapaan bos digunakan karena ikatan 
keduanya sudah terjalin dengan baik, sehingga sapaan tersebut tidak canggung diucapkan oleh mahasiswa tersebut kepada dosennya bahkan dianggap ucapan yang biasa saja antara mahasiswa I dengan dosen A.

\subsubsection{Sapaan Mahasiswa terhadap Pegawai Administrasi FKIP Universitas Halu Oleo}

Sapaan mahasiswa terhadap pegawai administrasi FKIP yang digunakan sehari-hari dalam melakukan urusan kampus, mahasiswa akan menyapa dan menggunakan sapaan yang umum, misalnya menggunakan sapaan Pak/Bapak, Bu/Ibu. Seperti yang diketahui sapaan tersebut bukan hanya dipakai pada saat menyapa pegawai administrasi tetapi juga biasa dipakai untuk menyapa dosen.

\section{Data 6}

Konteks:

Pada saat mahasiswa sedang melakukan pengurusan masalah akademik di dalam ruang perpustakaan FKIP Universitas Halu Oleo. Mahasiswa menghampiri pegawai perpustakaan yang saat itu selesai jam istirahat yaitu pukul 14:00. Berikut percakapan.

\section{Mahasiswa I:}

"Permisi Pak, saya mau mengurus keterangan bebas pustaka”.

Pegawai perpustakaan FKIP :

"Tulis nama dan stambuk

Analisis data:

Dari percakapan di atas terdapat kata sapaan Pak. Sapaan Pak dalam percakapan di atas digunakan oleh seorang mahasiswa untuk menyapa pegawai perpustakaan FKIP Universitas Halu Oleo. Percakapan dilakukan oleh mahasiswa I dengan pegawai perpustakaan FKIP. Terjadinya percakapan pada data tersebut adalah ketika seorang mahasiswa yang sedang melakukan pengurusan yakni meminta dibuatkan surat keterangan bebas pustaka. Mahasiswa menyapa pegawai perpustakaan dengan berkata "permisi Pak, saya mau mengurus keterangan bebas pustaka". Kemudian pegawai perpustakaan menjawab "tulis nama dan stambuk nanti besok pagi baru bisa diambil". Pegawai perpustakaan memberitahu mahasiswa besok baru bisa diambil karena pada saat itu mahasiswa tersebut mengurus keterangan bebas pustaka sudah pukul 14:00 dan pegawai perpustakaan juga memberitahu agar datang mengeceknya kembali besok pagi.

\subsubsection{Sapaan Mahasiswa terhadap Mahasiswa Seangkatan}

Dalam proses sapa menyapa yang dilakukan dalam kegiatan berkomukasi sehari-hari baik dalam ruangan maupun diluar ruang perkuliahan tentunya berbagai bentuk sapaan yang ditemukan tentulah sangat bervariasi. Karena seperti yang diketahui bahwa melalui perkembangan zaman yang sudah modern pastilah ditemukan berbagai bentuk sapaan atau penyapaan yang digunakan untuk menyapa orang lain, khusususnya di lingkungan mahasiswa Pendidikan Bahasa dan Sastra Indonesia FKIP Universitas Halu Oleo. Karena selain mereka adalah tingkat usia yang amat produktif dalam menggunakan sapaan juga dimungkinkan mereka memiliki berbagai variasi bentuk penyapaan. Dalam hal ini seorang mahasiswa akan menyapa mahasiswa yang setingkat atau seangkatannya menggunakan sapaan yang telah mereka sepakati bersama dan sudah menjadi kebiasaan sehari-hari dalam proses sapa menyapa. Misalnya sapaan yang digunakan untuk menyapa ketua kelas adalah dengan menggunakan sapaan keting (ketua tingkat), sapaan keting tersebut digunakan untuk menyapa ketua tingkat atau ketua dalam suatu ruangan yang disingkat menjadi keting. Di tiap-tiap kelas sudah pasti menggunakan sapaan Keting dalam berinteraksi dalam kegiatan sehari-hari. Hal tersebut dikarenakan mereka telah terbiasa menggunakan sapaan Keting tersebut. Selain itu juga dalam tiap kelas atau tiap ruangan juga menggunakan sapaan Bendahara. Sapaan tersebut adalah suatu kesepakatan bersama antara sesama mahasiswa. Bendahara merupakan wakil ketua kelas atau keting. Bendahara dalam suatu kelas atau ruangan adalah seseorang yang membantu dan mengurusi atau mengumpulkan iuran kelas.

\section{Data 7}

Konteks:

Pada saat mahasiswa sedang berada di sekitar ruang perkuliahan A3.5 Jurusan Pendidikan Bahasa dan Sastra Indonesia pada jam istirahat dan menunggu kuliah 
selanjutnya. Tiba-tiba datang seorang mahasiswa menghampiri dan menyapa mahasiswa yang ada di depan ruangan tersebut. Berikut percakapan.

Mahasiswa I : "Hei masuk kuliah ka tadi"?

Mahasiswa II : "Tidak jadi masuk dipindahkan jadwalnya minggu depan".

Mahasiswa I : "Saya buru-buru mi datang padahal tidak masuk”.

Analisis data:

Dari percakapan di atas terdapat kata sapaan Hei. Sapaan $\mathbf{H e i}$ merupakan kata sapaan yang sering digunakan oleh sesama mahasiswa dalam berinteraksi, percakapan dilakukan oleh mahasiswa I dengan mahasiswa II. Percakapan di atas ditujukan untuk menyapa sesama mahasiswa yang sudah saling kenal, sehingga tidak menyebutkan nama panggilan hanya menggunakan sapaan tersebut. Sapaan $\mathbf{H e i}$ yaitu sapaan seorang mahasiswa untuk menyapa temannya yang sesama mahasiswa Jurusan Pendidikan Bahasa dan Sastra Indonesia. Mahasiswa I menanyakan apakah masuk kuliah atau tidak, kemudian mahasiswa II menjawab bahwa tidak jadi masuk kuliah jadwalnya dipindahkan minggu depan.

\section{Data 8}

Konteks:

Pada saat mahasiswa sedang menunggu di depan ruangan dosen pada jam istrahat tepatnya pada pukul 12:00, tiba-tiba datang seorang mahsiswa yang hendak menitipkan berkas kepada mahasiswa yang berada di depan ruangan tersebut. Berikut percakapan.

Mahasiswa I : "Saya titip dulu berkasku di sini saya mau ke kantin”.

Mahasiswa II: "Anu jangan titip berkasmu di sini tidak ada yang liat soalnya saya mau pulangmi.

Mahasiswa I: "Saya hanya titip sebentar sa kembali lagi”.

Analisis data:

Dari percakapan di atas terdapat

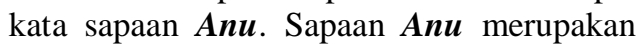
kata yang digunakan oleh sesama mahasiswa dalam proses sapa menyapa, percakapan dilakukan oleh mahasiswa I dengan mahasiswa II. Percakapan di atas ditujukan kepada sapaan sesama mahasiswa yang sudah saling kenal dan sapaan tersebut merupakan sapaan akrab yang digunakan oleh sesama mahasiswa Jurusan Pendidikan Bahasa dan Sastra Indonesia. Percakapan diatas merupakan percakapan yang di mana mahasiswa I memberitahu mahasiswa II untuk tidak menitipkan barangnya karena mahasiswa I juga sudah mau pulang ke kosnya.

\section{Data 9}

Konteks:

Pada saat mahasiswa Jurusan Pendidikan Bahasa dan Sastra Indonesia berada di sekitar ruang perkuliahan A3.2 dan menunggu dosen yang akan masuk mengajar, kemudian terdapat seorang mahasiswa yang baru saja sampai dan langsung menyapa mahasiswa yang berada di sekitar ruangan tersebut. Berikut percakapan

Mahasiswa I : "Woe sudah keluar ka dosennya"?

Mahasiswa II: "Dia belum datang dosennya, kamu tidak baca di drup ka kalau jadwalnya di ganti jam 08:30".

Mahasiswa I : "Saya tidak buka whatsApp (WA) karena tidak ada paketku”.

Analisis data:

Dari percakapan di atas terdapat kata sapaan Woe. Sapaan tersebut adalah data yang menunjukkan sapaan sesama mahasiswa yang sudah saling kenal dan sapaan tersebut merupakan sapaan akrab yang digunakan oleh sesama mahasiswa Jurusan Pendidikan Bahasa dan Sastra Indonesia. Percakapan dilakukan oleh mahasiswa I dengan mahasiswa II, sapaan woe yakni sapaan yang sering digunakan oleh sesama mahasiswa dalam proses sapamenyapa yang di mana terdapat mahasiswa I yang bertanya kepada mahasiswa II "apakah dosen yang mengajar sudah keluar atau belum", lalu mahasiswa II menjawab bahwa jadwal sebelumnya sudah diganti.

\section{Data 10}

Konteks:

Pada saat mahasiswa Jurusan Pendidikan Bahasa dan Sastra Indonesia menunggu dosen yang mau masuk mengajar di depan ruang kuliah A3.5 tepatnya pada pukul 09:30. Tiba-tiba datang seorang mahasiswa yang memberitahu temantemannya bahwa tidak jadi masuk. Berikut percakapan. 
Mahasiswa I : “Gais, dia tidak jadi
$\begin{aligned} & \text { masuk dosennya" } \\ & \text { Mahasiswa II : }\end{aligned}$
$\begin{aligned} & \text { diinformasikan di grup kalau tidak jadi } \\ & \text { masuk". }\end{aligned}$

Mahasiswa III : "Iya harusnya begitu supaya kita juga tidak menunggu”.

Mahasiswa I

: "Tidak diinformasikan di grub kar ena baru juga dikabari”.

Analisis data:

Dari percakapan di atas terdapat kata sapaan Gais. Percakapan bisa dirtikan untuk menyapa satu atau lebih dari satu orang temannya, interaksi terjadi ketika mahasiswa menyapa dan memberitahu teman-temannya bahwa dosen tidak jadi masuk mengajar dilakukan oleh mahasiswa I dengan mahasiswa II dan mahasiswa III, Sapaan gais adalah data yang menunjukkan sapaan sesama mahasiswa sehingga wajar bagi mahasiswa menggunakan sapaan tersebut dalam berinteraksi karena dianggap sebagai sapaan akrab. Sapaan Gais.

\section{Data 11}

\section{Konteks:}

Saat mahasiswa Jurusan Pendidikan Bahasa dan Sastra Indonesia sedang berada di sekitar ruang perkuliahan pada jam istirahat, terdapat seorang mahasiswa yang menghampiri dan menyapa mahasiswa yang berjalan menuju ruang kuliah A3.2. Berikut percakapan.

Mahasiswa I : "Kita sudah dari kantin $k a$ "?

Mahasiswa II : "Iya sudami saya barubaru dari kantin ini”".

Mahasiswa I : "padahal saya baru mau ajak ke kantin tapi kita sudah darimi”.

Analisis data:

Pedoman Umum Ejaan Bahasa Indonesia (PUEBI) arti kata kita adalah pronomina persona pertama jamak yang berbicara bersama dengan orang lain termasuk yang diajak bicara, sedangkan kata kita dalam bahasa sulawesi adalah kata yang dipakai sebagai bentuk menghargai orang yang diajak bicara, Percakapan dilakukan oleh mahasiswa I dengan mahasiswa II. Data di atas merupakan sapaan yang ditujukan kepada sesama mahasiswa. Sapaan Kita yaitu ditujukan pada saat menyapa temannya yang memiliki usia lebih tua dari si penyapa, sehingga mahasiswa I menyapa mahasiswa II menggunakan sapaan Kita.
Data 12

Konteks:

Pada saat mahasiswa berada di sekitar ruang Jurusan Pendidikan Bahasa dan Sastra Indonesia. Seorang mahasiswa menghampiri dan menyapa mahasiswa yang sedang berdiri sambil memainkan hand phone (Hp). Berikut percakapan.

Mahasiswa I : "Weh Dinda lamami sa tidak liat kamu”.

Mahasiswa II : "Iya soalnya saya jarang ke kampus".

Analisis data:

Dari percakapan di atas terdapat kata sapaan Dinda, percakapan dilakukan oleh mahasiswa I dengan mahasiswa II. Sapaan Dinda merupakan sapaan yang menunjukkan keakraban dan kekerabatan antara sesama mahasiswa. Sapaan tersebut berarti teman yang dalam proses sapa menyapa tidak menggunakan nama panggilan, walaupun sudah sama-sama saling mengenal satu sama lain. Sapaan pada data di atas sering digunakan pada saat berinteraksi sehari-hari. Jadi precakapan terjadi pada saat mahasiswa menyapa temannya yang sesama mahasiswa Jurusan Pendidikan Bahasa dan Sastra Indonesia.

\subsubsection{Sapaan Mahasiswa Junior terhadap Mahasiswa Senior}

Mahasiswa junior adalah mahasiswa yang tingkat semesternya lebih rendah, jadi sapaan yang digunakan juga berbeda-beda dan bertujuan untuk menghormati. Cara penyapaan yang digunakan oleh mahasiswa junior terhadap mahasiswa senior tentulah ada perbedaan. Kata lain mahasiswa junior adalah mahasiswa baru atau biasa disingkat maba yang merupakan mahasiswa yang baru menduduki bangku perkuliahan sedangkan, mahasiswa senior adalah mahasiswa yang telah lebih dulu menduduki bangku perkuliahan, itulah alasan mengapa dikatakan sebagai mahsiswa senior. Karena adanya perbedaan antara tingkatan setiap angkatan ini menyebabkan perbedaan bentuk penyapaan. Seperti yang telah kita ketahui bahwa dalam lingkungan perkuliahan proses berkomunikasi sehari-hari seseorang pasti saling sapa dengan orang orang lain baik itu dengan teman sebawanya, maupun dengan seniornya dikampus, dan 
mengganggap bahwa mahasiswa senior itu adalah mahasiswa yang sudah memiliki banyak pengalaman mengenai dunia kampus sehingga, mahasiswa junior sering mempunyai rasa takut ketika menyapa seniornya apalagi ketika mahasiswa junior dan mahasiswa senior itu tidak saling kenal dan saling akrab. Dan seperti yang telah diketahui bahwa bentuk penyapaan yang sering digunakan mahasiswa junior terhadap seniornya pasti menggunakan sapaan Kakak, Kanda, Bang, dan biasa juga menyapa dengan menggunakan sapaan Senior. Beikut ini adalah data yang mewakili ketika mahasiswa junior menyapa mahasiswa senior.

Konteks:

Pada saat mahasiswa berada di depan ruang perkuliahan A3.6 Jurusan Pendidikan Bahasa dan Sastra Indonesia. Seorang mahasiswa menghampiri dan menyapa mahasiswa yang berada di depan ruangan tersebut. Berikut percakapan.

Mahasiswa I : "Kakak toh yang program mata kuliah pragmatik di kelas B"?

Mahasiswa II : "Iya saya, kemarin saya tidak datang soalnya saya sakit”.

Mahasiswa I : "Tidak jadi masuk kemarin".

Analisis data:

Dari percakapan di atas terdapat kata sapaan Kakak. Percakapan dilakukan oleh mahasiswa I dengan mahasiswa II, sapaan Kakak merupakan kata untuk menyapa perempuan atau laki-laki yang lebih senior untuk menunjukan rasa akrab dan bertujuan untuk menghormati seniornya, sehingga menggunakan sapaan Kakak.

\section{Data 14}

Konteks:

Pada saat mahasiswa melakukan percakapan yang terdapat kata sapaan di sekitar ruang perkuliahan Jurusan Pendidikan Bahasa dan Sastra Indonesia FKIP. Berikut percakapan.

Mahasiswa I : "Bang, minta tolong kasi masuk juga saya di organisasinya kita”.

Mahasiswa II : "Oh iya nanti saya kasi masuk kalau kamu mau”.

Mahasiswa I : "Sebelumnya terima kasih bang".

Analisis data:
Dari percakapan di atas terdapat kata sapaan Bang, percakapan dilakukan oleh mahasiswa I dengan mahasiswa II. Sapaan Bang merupakan sapaan untuk menyapa mahasiswa laki-laki. Sapaan Bang sering digunakan dalam proses sapa menyapa di lingkungan kampus khususnya mahasiswa Jurusan Pendidikan Bahasa dan Sastra Indonesia apalagi dalam proses interaksi antara mahasiswa junior ketika menyapa mahasiswa senior data tersebut merupakan interaksi dari seorang junior dengan menggunakan sapaan bang terhadap seniornya karena telah lama kenal dan akrab.

\subsubsection{Sapaan Mahasiswa Senior terhadap Mahasiswa Junior \\ Mahasiswa senior adalah} mahasiswa yang tingkat semesternya lebih tinggi, jadi penggunaan sapaan yang digunakan tentunya harus tetap soapan yang bisa memberi hal positif terhadap juniornya, jadi sapaan yang digunakan adalah sapaan akrab yang tentunya tetap bersikap sebagai mahasiswa senior. Penggunaan sapaan antara mahasiswa senior terhadap mahasiswa junior juga memiliki perbedaan. Karena, semua mahasiswa senior mengganggap dirinya lebih tua dan lebih dulu memasuki bangku perkuliahan, dan tentu saja mengganggap akan disegani oleh mahasiswa junior. Maka dari itu pemakaian kata sapaan yang digunakan mahasiswa senior pada saat menyapa juniornya dalam kegiatan berinteraksi sehari-hari, adalah dengan menggunakan sapaan atau menyapanya dengan kata Dek. Sapaan Dek ini merupakan bentuk sapaan senior kepada juniornya. Karena, bagi mahasiswa senior kata Dek ini adalah suatu bentuk penyapaan yang akan selalu dipakai pada saat menyapa mahasiswa yang lebih muda darinya dan juga akan membuat seseorang itu akan mudah akarab walaupun tidak saling mengenal sebelumnya dan tidak malu-malu dalam menanyakan hal-hal yang berkaitan dengan masalah perkuliahan kepada seniornya. Selain itu juga katasapaan yang sering digunakan mahasiswa senior terhadap juniornya adalah dengan menggunakan sapaan atau bisa juga menyapanya dengan menggunakan "nama panggilan orang yang diajak bicara". Bentuk sapaan tersebut biasanya digunakan oleh orang yang sudah 
sama-sama saling kenal. Dengan demikian dalam proses penyapaan dalam kegiatan sehari-hari yang digunakan pada setiap mahasiswa khusunya jurusan pendidikan bahasa dan sastra Indonesia pastilah memiliki berbagai bentuk penyapaan yang digunakan dalam berkomunikasi.

\section{Data 15}

Konteks:

Pada saat mahasiswa sedang berada di depan ruang perkuliahan A3.6 Jurusan Pendidikan Bahasa dan Sastra Indonesia. Seorang mahasiswa menghampiri mahasiswa yang saat itu berada di depan ruangan tersebut dan percakapan yang dilakukan membahas masalah perkuliahan. Berikut percakapannya:

Mahasiswa I : "Dek, jam berapa kalian masuk mata kuliah kajian drama"?

Mahasiswa II : "Biasanya jam sebelas tapi dipindahkan jam satu”.

Analisis data:

Dari percakapan di atas terdapat kata sapaan Dek, percakapan dilakukan oleh mahasiswa I dengan mahasiswa II. Sapaan Dek merupakan kata sapaan yang digunakan oleh mahasiswa senior ketika menyapa mahasiswa junior baik itu laki-laki maupun perempuan. Mahasiswa senior adalah mahasiswa yang lebih dulu menduduki bangku perkuliahan, sedangkan mahasiswa junior biasa disebut mahasiswa yang tingkat semesternya masih rendah.

\subsubsection{Sapaan Mahasiswa terhadap Penjual di Sekitar Ruang Kuliah Gedung C Jurusan Pendidikan Bahasa dan Sastra Indonesia FKIP \\ Bentuk sapaan di lingkungan} mahasiswa Jurusan Pendidikan Bahasa dan Sastra Indonesia FKIP Universitas Halu Oleo tidak hanya terjadi pada saat bagaimana cara mahasiswa menyapa dosen, sapaan mahasiswa terhadap mahasiswa seangkatan, sapaan mahasiswa senior terhadap mahasiswa senior, sapaan mahasiswa senior terhadap mahasiswa junior, tetapi juga penggunaan bentuk sapaan juga terjadi pada penggunaan bentuk sapaan ketika mahasiswa menyapa penjual yang berada di lingkungan Jurusan Pendidikan Bahasa dan Sastra Indonesia FKIP Universitas Halu Oleo.
Data 16

Konteks:

pada saat mahasiswa menyapa penjual yang berada di sekitar ruang perkuliahan gedung C Jurusan Pendidikan Bahasa dan Sastra Indonesia FKIP. Percakapan tidak membahas masalah perkuliahan melainkan berinteraksi layaknya penjual dan pembeli. Berikut percakapan:

Mahasiswa I: " Tante, saya mau bayar harga gorengan lima dengan aqua gelas satu”.

Penjual : "Semuanya jadi enam ribu”.

Analisis data:

Dari percakapan di atas terdapat kata sapaan Tante, percakapan dilakukan oleh mahasiswa I dengan penjual yang berada di sekitar ruang kuliah gedung $\mathrm{C}$. Mahasiswa I berkata "Tante, saya mau bayar harga gorengan lima dengan aqua gelas satu, lalu penjual menjawab "semuanya jadi enam ribu". Sapaan Tante merupakan bentuk penyapaan untuk seorang penjual perempuan yang sering digunakan oleh mahasiswa Jurusan Pendidikan Bahasa dan Sastra Indonesia dalam berinteraksi. Konteks yang melatarbelakangi terjadinya percakapan adalah ketika seorang mahasiswa hendak membayar harga gorengan dan aqua kepada penjual yang berada di sekitar ruang kuliah gedung C Jurusan Pendidikan Bahasa dan Sastra Indonesia.

Data 17

Konteks:

Pada saat mahasiswa Jurusan Pendidikan Bahasa dan Sastra Indonesia ingin menukarkan uangnya kepada penjual yang berada di sekitar ruang kuliah gedung C Jurusan Pendidikan Bahasa dan Sastra Indonesia FKIP. Berikut percakapan.

Mahasiswa I : "Om adakah uang kecil saya mau tukar.

Penjual : "Ada ini uang lima ribuan, mau tukar uang berapaka”?

Mahasiswa I : "Uang lima puluh om".

Analisis data:

Dari percakapan di atas terdapat kata sapaan $\boldsymbol{O} \boldsymbol{m}$, percakapan dilakukan oleh mahasiswa I dengan penjual. Mahasiswa I bertanya “Om, adaka uang kecil saya mau tukar", kemudian penjual menjawab "ada ini uang lima ribuan, mau 
tukar uang berapaka"? lalu mahasiswa I menjawab kembali "uang lima puluh om. Pada data sapaan di atas terdapat sebuah konteks situasi yang melatar belakangi terjadinya sebuah tuturan yakni terdapat seorang mahasiswa yang menanyakan uang kecil untuk ditukarkan kepada penjual yang berada di sekitar ruang kuliah gedung C. Sapaan $\boldsymbol{O m}$ sering digunakan oleh mahasiswa Jurusan Pendidikan Bahasa dan Sastra Indonesia pada saat menyapa seorang penjual laki-laki yang memiliki usia lebih tua.

\section{PENUTUP}

\subsection{Kesimpulan}

Berdasarkan hasil penelitian yang telah dijelaskan dalam pembahasan, maka dapat disimpulkan sebagai berikut:

1. Sapaan di lingkungan mahasiswa Jurusan Pendidikan Bahasa dan Sastra Indonesia FKIP Universitas Halu Oleo , pemakaiannya didasari dari beberapa pertimbangan, yaitu berdasarkan kedudukan pembicara terhadap lawan bicaranya.

2. Sapaan mahasiswa Jurusan Pendidikan Bahasa dan Sastra Indonesia FKIP Universitas Halu Oleo ketika menyapa dosen yaitu menggunakan sapaan Pak apabila dosen tersebut adalah dosen laki-laki, dan menggunakan sapaan $\mathbf{I b u / B \boldsymbol { u }}$ apabila dosen tersebut adalah dosen perempuan.

3. Sapaan mahasiswa Jurusan Pendidikan Bahasa dan Sastra Indonesia FKIP Universitas Halu Oleo ketika mahasiswa menyapa pegawai administrasi. Bentuk sapaan Pak, $\mathrm{Ibu} / \mathrm{Bu}$.

4.

Sapaan mahasiswa Jurusan Pendidikan Bahasa dan Sastra Indonesia FKIP Universitas Halu Oleo ketika menyapa mahasiswa yang seangkatan maka sapaan yang digunakan adalah kata Bro. Sapaan Bro digunakan untuk menyapa mahasiswa yang sama-sama berjenis kelamin laki-laki, dan sapaan Bebs digunakan untuk menyapa mahasiswa yang sama-sama berjenis kelamin perempuan.

5. Sapaan mahasiswa Jurusan Pendidikan Bahasa dan Sastra Indonesia FKIP Universitas Halu Oleo. Sapaan mahasiswa junior terhadap mahasiswa senior adalah menggunakan kata Kak atau Kakak sapaan tersebut digunakan oleh mahasiswa laki-laki maupun mahasiswa perempuan untuk menyapa seniornya.

6

Sapaan mahasiswa Jurusan Pendidikan Bahasa dan Sastra Indonesia FKIP Universitas Halu Oleo. Sapaan mahasiswa senior terhadap mahasiswa junior adalah menggunakan kata Dek atau nama panggilan, sapaan tersebut digunakan oleh mahasiswa laki-laki maupun mahasiswa perempuan untuk menyapa juniornya.

7. Sapaan mahasiswa Jurusan Pendidikan Bahasa dan Sastra Indonesia FKIP Universitas Halu Oleo terhadap penjual yang berada di lingkungan ruang perkuliahan gedung C Jurusan Pendidikan Bahasa dan Sastra Indonesia adalah menggunakan sapaan Tante, Ibu, dan $\mathbf{O m}$.

\subsection{Saran}

Penelitian ini pada dasarnya dilakukan dalam rangka untuk mengkaji dan mengetahui bagaimana sapaan yang digunakan oleh mahasiswa Jurusan Pendidikan Bahasa dan Sastra Indonesia FKIP Universitas Halu Oleo. Mengingat ruang lingkup penelitian hanya pada mahasiswa Jurusan Pendidikan Bahasa dan Sastra Indonesia saja, tentunya gambaran dan informasi yang diperoleh hanya pada mahasiswa yang berstatus aktif kuliah pada jurusan pendidikan bahasa dan Sastra Indonesia. Sehubungan dengan hal tersebut, karena penelitian ini hanya mengkaji bentuk sapaan yang digunakan oleh mahasiswa, maka perlu diadakan penelitian lanjutan yang bersifat lebih mendalam mengenai sapaan bukan hanya yang digunakan oleh mahasiswa Jurusan Pendidikan Bahasa dan Sastra Indonesia tetapi juga sapaan yang digunakan pada tiap jurusan di Universitas Halu Oleo.

\section{DAFTAR PUSTAKA}

Chaer, Abdul., dan Agustina, Leonie. 2010. Sosiolinguistik. Jakarta: PT Rineka Cipta.

Dardjowidjojo, $\quad$ Soejono. 2014. Psikolinguistik Pengantar Pemahaman Bahasa Manusia. 
Jakarta: Yayasan Pustaka Obor Indonesia.

Kamma, Asis. 2015. Sapaan Dalam Bahasa Melayu Manado. Yogyakarta: Gama Media.

Lestari, Siti Rokhim dan Eva Dwi Kurniawan. 2011. Bahasa Indonesia. Yogyakarta: Perpustakaan Nasional.

Mahayana, Maman S. 2015. Bahasa Indonesia Kreatif. Jakarata: Penaku.

Martina, dan Irmayani. 2004. Sistem Sapaan. Jakarta: Pusat Bahasa.

Mulya, Abdul Kadir, dkk. 2004. Sistem Sapaan Bahasa Tolaki. Jakarta: Pusat Bahasa.

Pateda, Mansoer. 1987. Sosiolinguistik. Bandung: Angkasa.

Sugihastuti. 2014. Bahasa Laporan Hasil Penelitian. Yogyakarta: Pustaka Pelajar.

Sugono, Dendy. 2003. Buku Praktis Bahasa Indonesia. Jakarta: Pusat Bahasa.

Suhaebah, Ebah, dkk. 2007. Antologi Kajian Kebahasaan. Jakarta: Pusat Bahasa.

Suharyanto, dkk. 2008. Sistem Sapaan dalam Bahasa Mai Brat. Jayapura: Balai Bahasa Jayapura.

Sukmawati. 2006. Sistem Sapaan Bahasa Muna. Kendari: Kantor Bahasa Provinsi Sulawesi Tenggara.

Sulastri, Leni. 2012. Antologi Hasil Penelitian Bahasa dan Sasta. Jambi: Kantor Bahasa Provinsi Jambi.

Sulastri, Leni. 2014. Antologi Hasil Penelitian Bahasa dan Sastra. Jambi: Kantor Bahasa Provinsi Jambi. 